\title{
Immunotherapy and chronic myelomonocytic leukemia
}

\author{
Nepton Sheik Khoni ${ }^{1 *}$ and Gayathri Balasubramanian ${ }^{2}$ \\ ${ }^{1}$ Global Allied Pharmaceutical, Center for Excellence in Research \& Development, 160 Vista Oak Dr. Longwood, FL 32779, USA \\ ${ }^{2}$ Phamax Market Access Solutions, \#19, KMJ Ascend 1st Cross, 17th C Main 5th Block, Koramangala, Bangalore - 560 095, India
}

\begin{abstract}
Researchers have constantly been exploring the field of immunotherapy for diseases like chronic myelomonocytic leukemia (CMML) to improve the success rate and decrease disease burden. Currently approved treatment aim at providing the best supportive care. However, it is believed that with the development in stem cell transplantation, targeted therapies and vaccines, the patients will be able to live a healthier life. To achieve this, exhaustive knowledge of the disease presentation, risk factors, pathophysiology and diagnosis is important. The identification of the association between various genetic mutations and Myeloproliferative disorders (MPDs) has shed some light on the path to development of novel therapies. Few drugs and vaccines are under clinical trials in Phase I and II. In addition, the potential of combination therapies in improving clinical outcomes also needs to be explored. Considering all of the above, the following review is focused on providing a holistic view of CMML and the current developments in the field of immunotherapy related to this disease.
\end{abstract}

\begin{abstract}
Abbreviations: ADP: Adenosine Di Phosphate; AMP: Adenosine Mono Phosphate; AML: Acute myeloid leukemia; ASXL1: Additional sex combs like transcriptional regulator 1; CMML: Chronic Myelomonocytic Leukemia; CSF3R: Colony Stimulating Factor 3 Receptor; DNA: Deoxyribonucleic acid; DNMT3A: DNA (cytosine-5)methyltransferase 3A; DT: Diphtheria toxin; EF-2: Elongation factor 2; ET: Essential Thrombocythemia; EZH2: Enhancer of zeste 2 polycomb repressive complex 2 subunit; FDA: Food and Drug Administration; GM-CSF: Granulocyte-macrophage colony-stimulating factor; IFN: Interferon; IL3: Interleukin 3; JAK: Janus Kinase; MMM: Myeloid Metaplasia; MPDs: Myeloproliferative disorders; PV: Polycythemia Vera; RNA: Ribonucleic acid; RUNX1: Runt-related transcription factor 1; SETBP1: SET Binding Protein 1; SRSF2: Serine/arginine-rich splicing factor 2; TET2: tet methyl cytosine dioxygenase 2; WBC: White blood cells; WHO: World Health Organization; ZRSR2: Zinc finger (CCCH type) RNA-binding motif and serine/arginine rich 2.
\end{abstract}

\section{Introduction/Epidemiology}

Myeloproliferative disorders (MPDs) are classified according to the most affected type of blood cells. There are four main types of MPDs, namely, Polycythemia Vera (PV), Essential thrombocythemia (ET), Myelofibrosis with Myeloid Metaplasia (MMM), and Chronic myelomonocytic leukemia (CMML).

CMML is a form of leukemia characterized by increased numbers of monocytes in the blood and bone marrow. According to the World Health Organization (WHO), CMML is classified into two subtypes based on the percentage of blast cells found in the blood and marrow: CMML-1 (less than 5 percent blasts in the blood and less than 10 percent blasts in the marrow). CMML-2 (5 to 19 percent blasts in the blood and 10 to 19 percent blasts in the marrow) [1,2]. CMML type 1 or 2, with increased number of eosinophils, are considered another specific sub-classification of CMML. CMML is rare. For example, it occurs only in four out of one million people in the United States, i.e., 1,100 cases occur each year. This disease is rare in young people. Almost 9 out of 10 cases are diagnosed in people aged 60 and above. The male to female ratio is 2:1 and the median age at presentation is 65-
75 years. The disease has both myeloproliferative and myelodysplastic features [3].

\section{Etiology/predisposing factors [3-6]}

The causes of chronic MPDs remain unknown. However, an association between mutation of a particular gene known as Janus kinase 2 (JAK 2) is found in a large proportion of people with MPDs. Several risk factors associated with chronic MPDs and CMML have been identified. Some of them are:

\section{Age and sex}

PV is more common in men than in women. The condition is rarely seen in the people under the age of 40 , but a few cases have been diagnosed among children. The risk of CMML increases with age. This disease is rare in those younger than 40 , with most cases found in people aged 60 and above. CMML is about twice as common in men as in women.

\section{History of cancer treatment}

Prior treatment with chemotherapy seems to increase the risk of CMML. The risk of CMML after cancer chemotherapy, however, is not as high as the risk of other blood problems, such as myelodysplastic syndromes and acute myeloid leukemia.

\section{Exposure to petrochemicals}

Benzene, Toluene and ionizing radiation increases the risk of MMM.

Correspondence to: Dr. Nepton Sheik Khoni, MD, Ph.D., Global Allied Pharmaceutical, Center for Excellence in Research and Development, 160 Vista Oak Dr. Longwood, FL 32779, USA, Tel: 1-321-945-4283; E-mail: timothy.allen@gapsos.com

Key words: CMML; cytokine; stem cell; MPDs

Received: June 10, 2016; Accepted: June 22, 2016; Published: June 25, 2016 


\section{Pathophysiology/molecular basis of CMML}

Mutations such as epigenetic regulator genes, spliceosome component pathway, transcription factors and signaling regulator genes are found in about $90 \%$ of patients with CMML,

\section{Epigenetic regulator gene mutations}

Mutations in tet methyl cytosine dioxygenase 2 (TET2) are detected in 40-60\% of patients with CMML [7-10]. Deoxyribonucleic acid (DNA) (cytosine-5)-methyltransferase 3A (DNMT3A) mutations tend to occur in CMML-2 and 6 of 20 patients are reported to have CMML-derived acute myeloid leukemia (AML) [8]. Additional sex combs like transcriptional regulator 1 (ASXL1) mutations are detected in $40-50 \%$ of patients with CMML. Itzykson, Patnaik and Padron, Gelsi-Boyer $[7,11,12]$ who are reported to have a higher white blood cells (WBC) count, higher levels of monocytes and immature myeloid cells in the blood [7,11]. However, the controversy surrounding the prognostic impact of ASXL1 mutations on survival requires resolution. The conclusions derived from two large series of experiments are contradictory. Itzykson et al., reported that, ASXL1 mutation is an unfavorable independent prognostic factor [7]. On the other hand, data from Patnaik et al., showed that ASXL1 mutations have no impact on survival [11]. Additionally, mutations of enhancer of zeste 2 polycomb repressive complex 2 subunit (EZH2) are found to be uncommon in CMML [7].

\section{Spliceosome component mutations}

About $60 \%$ of patients with CMML have mutations in genes involved in Ribonucleic acid (RNA)-splicing [7]. Most common are the mutations in the serine/arginine-rich splicing factor 2 (SRSF2) in $30-50 \%$ of cases. These mutations are associated with increased age, less pronounced anemia and a diploid karyotype, but not with prognosis [7,13-15]. SRSF2 or zinc finger (CCCH type). RNA-binding motif and serine/arginine rich 2 (ZRSR2) mutations are frequently concordant with TET2 mutations $[7,13,16]$.

\section{Mutations affecting tanscription}

Mutations in the runt-related transcription factor 1 (RUNX1) are detected in $15-40 \%$ of patients with CMML $[7,17-19]$ Patients with CMML and RUNX1 mutations may have a higher risk of transformation to AML. CCAAT/enhancer binding protein, alpha (CEBPA) mutations are rare in patients with CMML [19].

\section{Signaling regulator gene mutations}

Kosmider et al., reported variant Colony Stimulating Factor 3 Receptor (CSF3R) somatic mutations in about $4 \%$ of patients with CMML with high concordance for ASXL1 mutations [20]. Poor prognosis was seen in these patients. SET Binding Protein 1 (SETBP1) mutations are detected in about 5\% of patients with CMML and are associated with a poor prognosis in patients who also have an ASXL1 mutation [20-22]. Cbl proto-oncogene, E3 ubiquitin protein ligase (CBL) mutations are detected in about $10 \%$ of patients with CMML [23-25].

\section{Immunotherapy in CMML}

\section{Cytokine therapy}

Non-food and drug administration (FDA) approved drug: SL401: It is a recombinant protein consisting of human interleukin 3 (IL3) fused to the first 388 amino acids of diphtheria toxin [DT(388)]
(DT388IL3) with potential antineoplastic activity. Upon intravenous administration, the IL3 moiety of the DT(388)IL3 fusion protein, SL-401, binds to the IL3 receptors on cells expressing the receptor. Subsequently, the DT(388) toxin moiety, which contains both translocation and catalytic domains, is transported across the cell membrane via endocytosis. Within the cytosol, the catalytic domain of the toxin catalyzes the Adenosine Di Phosphate (ADP)-ribosylation of and inactivates the translation elongation factor 2 (EF-2), inhibiting the translation during protein synthesis. IL3 may be over expressed by a variety of cancers, including blastic plasmacytoid dendritic cell neoplasm and acute myeloid leukemia (AML) (Table 1).

\section{Stem cell transplantation}

In allogeneic stem cell transplantation, the patient receives stem cells from either a related or unrelated matched donor. It has been used to treat and sometimes cure CMML patients. However, because allogeneic stem cell transplantation is associated with a relatively high mortality risk that increases with patient age, most CMML patients are not eligible for this therapy. It is an option for a small number of patients, generally younger patients with an advanced disease, who have either failed to respond to or no longer respond to other treatment and who have an appropriate stem cell donor. Allogeneic stem cell transplant can have serious, even fatal, side effects and so is rarely used in elderly patients. Ongoing clinical trials for reduced-intensity allogeneic stem cell transplantation may prove effective and hence more patients can avail this treatment option in the future [27].

\section{Vaccine}

Non-FDA approved vaccine: Bystander Vaccine: It is a cellbased vaccine composed of irradiated tumor cells transduced with granulocyte-macrophage colony-stimulating factor (GM-CSF) and CD40-ligand (CD40L) genes. Upon administration, this vaccine may stimulate an anti-tumoral dendritic cell-mediated host immune response (Table 2).

\section{Conclusion}

The success rate in treating hematological malignancies is increasing and advancing day-by-day with the enhancing knowledge on the function of the immune system. Researchers are still challenged when exploring innate and adaptive immune systems. The identification of the JAK2-V617F mutations in chronic MPDs has stimulated a great deal of effort in screening and developing specific inhibitors for clinical use. It is certain that the next few years will bring further developments in this fast-evolving field. Immunotherapy is believed to be very promising in the field of cancer. The recent activities have increased our understanding of the tumor microenvironment, various immunotherapeutic modalities or combination therapies (like chemotherapy with immunotherapy). The effects of such modalities

Table 1. Non-FDA Approved cytokine therapy [26].
\begin{tabular}{|l|l|l|l|l|}
\hline Drug & $\begin{array}{l}\text { Clinical trial } \\
\text { identifier no. }\end{array}$ & Phase & Study Design & Target \\
\hline SL-401 & NCT 02268253 & $\begin{array}{l}\text { Phase } \\
\text { I, II }\end{array}$ & $\begin{array}{l}\text { Non Randomized, Safety/Efficacy Study } \\
\text { Open Label }\end{array}$ & $\begin{array}{l}\text { IL3 } \\
\text { receptors }\end{array}$ \\
\hline
\end{tabular}

Table 2. Non-FDA Approved Vaccine [28].

\begin{tabular}{|l|l|l|l|l|}
\hline Drug & $\begin{array}{l}\text { Clinical trial } \\
\text { identifier no. }\end{array}$ & Phase & Study Design & Target \\
\hline $\begin{array}{l}\text { Bystander } \\
\text { vaccine }\end{array}$ & NCT00840931 & Phase I & $\begin{array}{l}\text { Safety/Efficacy Study } \\
\text { Open Label }\end{array}$ & Cell lysis \\
\hline
\end{tabular}


in combination with immunotherapy in cancer patients are still in the exploratory phase. The complete perspective of immunotherapy treatment has not been realized and/or utilized yet. In this respect, proper preclinical and clinical designs are important pillars in understanding the future of immunotherapy in treating cancer patients.

\section{References}

1. Beating blood cancers (2011) Leukaemia \& Lymphoma Research, 39-40 Eagle Street, London WC1R $4^{\text {th }}$ T: 0207405010.

2. Lichtman MA, Beutler E, Kipps TJ, Seligsohn U, Kaushansky K, et al. (2006) Chronic myelogenous leukemia and related disorders. Williams Hematology: 1261-1268.

3. Risk factors for chronic myelomonocytic leukemia. American Cancer Society.

4. MPN Research Foundation. Polycythemia vera (PV).

5. Siamak N. Nabili (2016) Polycythemia (Elevated Red Blood Cell Count). Medicinenet.com

6. Lichtman MA, Tefferi A (2012) Primary myelofibrosis. Kipps TJ, Seligsohn U, Kaushansky K, Prchal JT (Eds) Williams Hematology.

7. Itzykson R, Kosmider O, Renneville A, Gelsi-Boyer V, Meggendorfer M, et al. (2013) Prognostic score including gene mutations in chronic myelomonocytic leukemia. J Clin Oncol 31: 2428-2436. [Crossref]

8. Jankowska AM, Makishima H, Tiu RV, Szpurka H, Huang Y et al. (2011) Mutational spectrum analysis of chronic myelomonocytic leukemia includes gene associated with epigenetic regulation: UTX, EZH2, and DNMT3A. Blood 118: 3932-3941. [Crossref]

9. Kosmider O, Boyer VG, Ciudad M,Racoeur C, Jooste V, et al. (2009) TET2 gene mutations is a frequent and adverse event in chronic myelomonocytic leukemia. Haematologica 94: 1676-1681.

10. Tefferi A, Lim KH, Wahab OA, Lasho TL, Patel J, et al. (2009) Detection of mutant TET2 in myeloid malignancies other than myeloproliferative neoplasms: CMML, MDS, MDS/ MPN and AML. Leukemia 23: 1343-1345. [Crossref]

11. Patnaik MM, Padron E, LaBorde RR, Lasho TL, Finke CM, et al. (2013) Mayo prognostic model for WHO-defined chronic myelomonocytic leukemia: ASXL1 and spliceosome component mutations and outcomes. Leukemia 27: 1504-1510. [Crossref]

12. Boyer GV, Trouplin V, Adélaïde J, Bonansea J, Cervera N, et al. (2009) Mutations of polycomb-associated gene ASXL1 in myelodysplastic syndromes and chronic myelomonocytic leukaemia. Br J Haematol 145: 788-800. [Crossref]

13. Meggendorfer M, Roller A, Haferlach T, Eder C, Dicker F, et al. (2012) SRSF2 mutations in 275 cases with chronic myelomonocytic leukemia (CMML). Blood 120: 3080-3088. [Crossref]

14. Kar SA, Jankowska A, Makishima H, Visconte V, Jerez A, et al. (2013) Spliceosomal gene mutations are frequent events in the diverse mutational spectrum of chronic myelomonocytic leukemia but largely absent in juvenile myelomonocytic leukemia. Haematologica 98: 107-113. [Crossref]
15. Patnaik MM, Lasho TL, Finke CM, Hanson CA, Hodnefield JM, et al. (2013) Spliceosome mutations involving SRSF2, SF3B1, and U2AF35 in chronic myelomonocytic leukemia: prevalence, clinical correlates, and prognostic relevance. Am J Hematol 88: 201-206. [Crossref]

16. Malcovati L, Papaemmanuil E, Ambaglio I, Elena C, Gallì A, et al. (2014) Driver somatic mutations identify distinct disease entities within myeloid neoplasms with myelodysplasia. Blood 124: 1513-1521. [Crossref]

17. Kuo MC, Liang DC, Huang CF, Shih YS, Wu JH, et al. (2009) RUNX1 mutations are frequent in chronic myelomonocytic leukemia and mutations at the C-terminal region might predict acute myeloid leukemia transformation. Leukemia 23: 1426-1431. [Crossref]

18. Boyer VG, Trouplin V, Adélaïde J, Aceto N, Remy V, et al. (2008) Genome profiling of chronic myelomonocytic leukemia: frequent alterations of RAS and RUNX1 genes. BMC Cancer 8: 299.

19. Ernst T, Chase A, Zoi K, Waghorn K, Curtis HC, et al. (2010) Transcription factor mutations in mutations in myelodysplastic/myeloproliferative neoplasms. Haematologica 95: 1473-1480. [Crossref]

20. Kosmider O, Itzykson R, Chesnais V, Lasho T, Labordeet R, et al. (2013) Mutations of the colony-stimulating factor-3 receptor gene is a rare event with poor prognosis in chronic myelomonocytic leukemia. Leukemia 27: 1946-1949.

21. Damm F, Itzykson R, Kosmider O, Droin N, Renneville A, et al. (2013) SETBP1 mutations in 658 patients with myelodysplastic syndromes, chronic myelomonocytic leukemia and secondary acute myeloid leukemias. Leukemia 27: 1401-1403. [Crossref]

22. Laborde RR, Patnaik MM, Lasho TL, Finkeet CM, Hansonal CA, et al. (2013) SETBP mutations in 415 patients with primary myelofibrosis or chronic myelomonocytic leukemia: independent prognostic impact in CMML. Leukemia 27: 2100-2102. [Crossref]

23. Kohlmann A, Grossmann V, Klein HU, Schindela S, Weiss T, et al. (2010) Nextgeneration sequencing technology reveals a characteristic pattern of molecular mutations in $72.8 \%$ of chronic myelomonocytic leukemia by detecting frequent alterations in TET2, CBL, RAS, and RUNX1. J Clin Oncol 28: 3858-3865. [Crossref]

24. Makishima H, Cazzolli H, Szpurka H, Dunbar A, Tiu R, et al., (2009) Mutations of e3 ubiquitin ligase cbl family members constitute a novel common pathogenic lesion in myeloid malignancies. J Clin Oncol 27: 6109-6116. [Crossref]

25. Sanada M, Suzuki T, Shih LY, Otsu M, Kato M, et al. (2009) Gain-of-function of mutated C-CBL tumor suppressor in myeloid neoplasms. Nature 460: 904-908. [Crossref]

26. SL-401 in Advanced, High Risk Myeloproliferative Neoplasms (Systemic Mastocytosis, Advanced Symptomatic Hypereosinoophic Disorder, Myelofibrosis, Chronic Myelomonocytic Leukemia). Stemline Therapeutics, Inc. ClinicalTrials.gov.

27. Emanuel PD (2008) Juvenile myelomonocytic leukemia and chronic myelomonocytic leukemia. Spotlight Review. Leukemia 22: 1335-1342.

28. Immunotherapy Using Lenalidomide + Bystander Vaccine in High Risk Myelodysplastic Syndrome (MDS). H Lee Moffitt Cancer Center and Research Institute. ClinicalTrials.gov.

Copyright: $\odot 2016$ Khoni NS. This is an open-access article distributed under the terms of the Creative Commons Attribution License, which permits unrestricted use, distribution, and reproduction in any medium, provided the original author and source are credited. 